\title{
Streptomyces sedi sp. nov., isolated from surface-sterilized roots of Sedum sp.
}

\author{
Correspondence \\ Wen-Jun Li \\ wjli@ynu.edu.cn \\ or \\ liact@hotmail.com
}

\author{
Jie Li, ${ }^{1}$ Guo-Zhen Zhao, ${ }^{1}$ Sheng Oin, ${ }^{1}$ Wen-Yong Zhu, ${ }^{1}$ Li-Hua Xu ${ }^{1}$ \\ and Wen-Jun $\mathrm{Li}^{1,2}$
}
${ }^{1}$ The Key Laboratory for Microbial Resources of the Ministry of Education, PR China, and Laboratory for Conservation and Utilization of Bio-Resources, Yunnan Institute of Microbiology, Yunnan University, Kunming 650091, PR China
${ }^{2}$ Guangdong Key Laboratory of Marine Materia Medica, South China Sea Institute of Oceanology, Chinese Academy of Sciences, Guangzhou 510301, PR China

The genus Streptomyces was proposed by Waksman \& Henrici (1943) and currently encompasses more than 500 species with validly published names. It has been proposed that the genus is underspeciated (Sembiring et al., 2000; Kim \& Goodfellow, 2002) and that the description of novel Streptomyces species needs to be based on a combination of genotypic and phenotypic data (Manfio et al., 1995, 2003; Atalan et al., 2000; Li et al., 2002).

Streptomycetes are still a rich source of useful compounds, notably antibiotics, enzymes, enzyme inhibitors and pharmacologically active agents (Bérdy, 2005). During a search for novel endophytic microbes, strain YIM $65188^{\mathrm{T}}$ was isolated from surface-sterilized plant tissues. The objective of the present study was to determine the taxonomic position of strain YIM $65188^{\mathrm{T}}$.

Strain YIM $65188^{\mathrm{T}}$ was isolated from the surface-sterilized tissue of Sedum sp., which was collected from Yunnan

Abbreviation: ISP, International Streptomyces Project.

The GenBank/EMBL/DDBJ accession number for the 16S rRNA gene sequence of strain YIM $65188^{\top}$ is EU925562. province, south-west China. In the open, the plant was tagged and stored in a clean plastic bag until used (approx. $24 \mathrm{~h}$ ). The plant sample was then washed thoroughly in running water to remove all soil. A sonication step, carried out at $160 \mathrm{~W}$ with an exposure time of $15 \mathrm{~min}$, was employed to dislodge any soil and organic matter from the sample surface. The plant sample was then cut up with a sterilized knife. The tissue segments were surface-sterilized according to the method of Coombs \& Franco (2003). The surface-sterilization process was verified by aseptic rolling of the surface-sterilized plant material on isolation medium and tryptic soy agar (TSA; Difco) and then incubating the plates at $28{ }^{\circ} \mathrm{C}$ for 7 days. The surface-sterilized tissues were then blended aseptically in a commercial blender and plated on sodium propionate agar $\left(1^{-1}: 1 \mathrm{~g}\right.$ sodium propionate, $0.2 \mathrm{~g}$ L-asparagine, $0.9 \mathrm{~g} \quad \mathrm{KH}_{2} \mathrm{PO}_{4}, 0.6 \mathrm{~g}$ $\mathrm{K}_{2} \mathrm{HPO}_{4}, 0.1 \mathrm{~g} \mathrm{MgSO}_{4} .7 \mathrm{H}_{2} \mathrm{O}, 0.02 \mathrm{~g} \mathrm{CaCl}_{2} .2 \mathrm{H}_{2} \mathrm{O}, 18 \mathrm{~g}$ agar; pH 7.2) followed by incubation at $28{ }^{\circ} \mathrm{C}$ for up to 4 weeks. The purified strain was cultured routinely on YIM 38 medium $\left[1^{-1}: 4 \mathrm{~g}\right.$ malt extract, $4 \mathrm{~g}$ yeast extract, $4 \mathrm{~g}$ glucose, vitamin mixture $(0.5 \mathrm{mg}$ each of thiamine$\mathrm{HCl}$, riboflavin, niacin, pyridoxine- $\mathrm{HCl}$, inositol, calcium 
pantothenate and p-aminobenzoic acid, plus $0.25 \mathrm{mg}$ biotin), 20 g agar; $\mathrm{pH} 7.2 \mathrm{]}$ at $28{ }^{\circ} \mathrm{C}$ and stored as a glycerol suspension $(20 \%, \mathrm{v} / \mathrm{v})$ at $-70{ }^{\circ} \mathrm{C}$.

Cultural characteristics were determined after 2 weeks incubation at $28{ }^{\circ} \mathrm{C}$, according to the methods of the International Streptomyces Project (ISP; Shirling \& Gottlieb, 1966). Czapek's agar and nutrient agar were prepared as described by Dong \& Cai (2001). Colour determination was performed by using colour chips from the ISCC-NBS colour charts (standard samples, no. 2106; Kelly, 1964). After incubation on YIM 38 medium at $28{ }^{\circ} \mathrm{C}$ for 14 days, morphological properties were examined by using a light microscope (BH-2; Olympus) and a scanning electron microscope (Philips XL30; ESEM-TMP).

Carbon-source utilization was determined according to the methods of Shirling \& Gottlieb (1966) and Locci (1989). Acid production from carbohydrates was assessed as described by Gordon et al. (1974). Growth at various temperatures, $\mathrm{pH}$ values and $\mathrm{NaCl}$ concentrations was examined according to $\mathrm{Xu}$ et al. (2005), using YIM 38 medium as the basal medium. Oxidase activity was determined from the oxidation of tetramethyl-p-phenylenediamine. Catalase activity was determined with $3 \%$ $\mathrm{H}_{2} \mathrm{O}_{2}$ according to standard methods. Other phenotypic characteristics were tested by using standard procedures (Goodfellow, 1971; Williams et al., 1983).

Strain YIM $65188^{\mathrm{T}}$ grew well on nutrient agar, with moderate growth on yeast extract-malt extract agar (ISP 2), inorganic salts-starch agar (ISP 4) and Czapek's agar, and poor growth on oatmeal agar (ISP 3) and glycerolasparagine agar (ISP 5). White aerial mycelia formed more slowly on ISP 2, ISP 4 and Czapek's agar than on nutrient agar. Aerial mycelia were not formed on ISP 3 or ISP 5 media. The vegetative mycelia were yellow-white in colour on ISP 3, ISP 4, ISP 5 and Czapek's agar, light grey-yellow on ISP 2 agar medium, and pale orange-yellow on nutrient agar. Soluble pigments were not produced on any of the media tested. Spore chains were of the Spirales type, spores were elliptical or short rods and the spore surface was smooth (Fig. 1). Detailed physiological results are given in Table 1 and in the species description.

For chemotaxonomic analysis, freeze-dried cells were obtained from cultures grown in YIM 38 broth for 1 week at $28{ }^{\circ} \mathrm{C}$. The isomer of diaminopimelic acid and sugars of whole-cell hydrolysates were determined by using TLC as described by Staneck \& Roberts (1974). Phospholipids were identified according to published procedures (Minnikin et al., 1979; Collins \& Jones, 1980). Menaquinones were extracted (Collins et al., 1977) and separated by HPLC (Tamaoka et al., 1983). The G + C contents of the genomic DNAs were determined by the HPLC method according to Mesbah et al. (1989).

Strain YIM $65188^{\mathrm{T}}$ contained LL-diaminopimelic acid as the diamino acid. Whole-cell hydrolysates contained glucose, galactose and madurose. Diphosphatidylglycerol

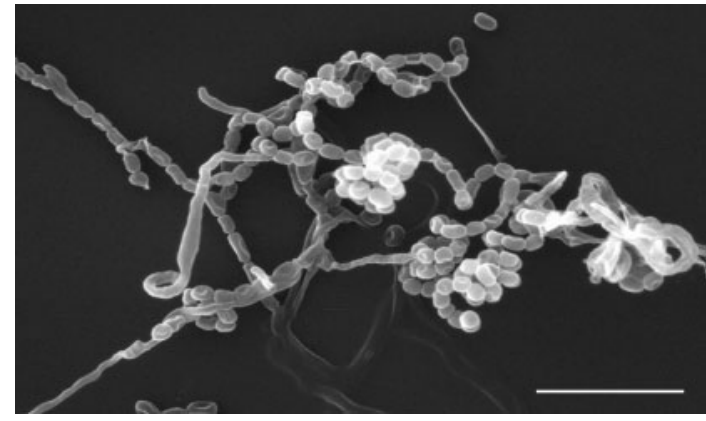

Fig. 1. Scanning electron micrograph of spore chains of strain YIM $65188^{\top}$ after growth on YIM 38 medium at $28^{\circ} \mathrm{C}$ for 14 days. Bar, $5 \mu \mathrm{m}$.

was the major phospholipid, with moderate amounts of phosphatidylethanolamine, phosphatidylglycerol and phosphatidylinositol and minor to trace amounts of two phosphatidylinositol mannosides and four unknown phospholipids. According to Kim et al. (2003), the predominant menaquinones of members of the genus Streptomyces are MK-9 $\left(\mathrm{H}_{6}\right)$ and MK-9 $\left(\mathrm{H}_{8}\right)$. Strain YIM $65188^{\mathrm{T}}$ has an unusual quinone composition, with the predominant menaquinones being MK-11( $\left.\mathrm{H}_{6}\right)$, MK-10 $\left(\mathrm{H}_{6}\right)$, MK$10\left(\mathrm{H}_{8}\right)$, MK-11( $\left.\mathrm{H}_{8}\right)$, MK-9 $\left(\mathrm{H}_{8}\right), \quad$ MK-12( $\left.\mathrm{H}_{6}\right)$, MK-

Table 1. Physiological characteristics that differentiate strain YIM $65188^{\top}$ from its closest phylogenetic neighbours, S. specialis GW41-1564 ${ }^{\top}$ and S. hainanensis YIM $47672^{\top}$

Taxa: 1, strain YIM $65188^{\mathrm{T}} ; 2$, S. specialis GW41-1564 ${ }^{\mathrm{T}} ; 3$, S. hainanensis YIM $47672^{\mathrm{T}}$ (Jiang et al., 2007). Characteristics were scored as follows: + , positive; - , negative; ND, undetermined.

\begin{tabular}{|lccc|}
\hline Characteristic & $\mathbf{1}$ & $\mathbf{2}$ & $\mathbf{3}$ \\
\hline Starch hydrolysis & - & - & + \\
Utilization as sole carbon source: & & & \\
Cellobiose & + & - & + \\
Aesculin & + & - & + \\
D-Fructose & + & - & - \\
Inositol & - & + & - \\
Maltose & + & - & - \\
D-Ribose & - & + & - \\
Trehalose & - & - & + \\
Utilization as sole nitrogen source: & & & \\
Adenine & - & + & $\mathrm{ND}$ \\
L-Asparagine & - & + & $\mathrm{ND}$ \\
L-Cysteine & + & - & $\mathrm{ND}$ \\
L-Histidine & + & - & $\mathrm{ND}$ \\
Hypoxanthine & - & + & $\mathrm{ND}$ \\
DL-Methionine & + & - & $\mathrm{ND}$ \\
L-Phenylalanine & - & + & $\mathrm{ND}$ \\
L-Threonine & - & + & $\mathrm{ND}$ \\
L-Valine & - & + & $\mathrm{ND}$ \\
Xanthine & - & + & $\mathrm{ND}$ \\
& & & \\
& & & \\
\hline
\end{tabular}


$11\left(\mathrm{H}_{4}\right)$, MK-9 $\left(\mathrm{H}_{6}\right)$ and $\mathrm{MK}-10\left(\mathrm{H}_{4}\right)$ in the ratio $27: 23: 10: 10: 9: 6: 5: 4: 4$. Minor amounts of MK$12\left(\mathrm{H}_{4}\right)$ were detected. In order to verify the result, analysis of an independently grown biomass of YIM $65188^{\mathrm{T}}$ was carried out. A similar quinone profile was observed, which was composed of the compounds MK-11( $\left.\mathrm{H}_{6}\right), \mathrm{MK}-10\left(\mathrm{H}_{6}\right)$, MK-10 $\left(\mathrm{H}_{4}\right)$, MK-11 $\left(\mathrm{H}_{4}\right)$, MK-11 $\left(\mathrm{H}_{8}\right)$, MK-10 $\left(\mathrm{H}_{8}\right)$, MK$9\left(\mathrm{H}_{8}\right)$ and $\mathrm{MK}-9\left(\mathrm{H}_{6}\right)$ in the ratio $27: 24: 11: 9: 8: 7: 7: 7$. The quinone system of Streptomyces specialis GW41-1564 ${ }^{\mathrm{T}}$ was investigated simultaneously, and was found to consist of MK-10 $\left(\mathrm{H}_{4}\right), \mathrm{MK}-10\left(\mathrm{H}_{6}\right), \mathrm{MK}-9\left(\mathrm{H}_{6}\right), \mathrm{MK}-9\left(\mathrm{H}_{4}\right)$ and MK-10 $\left(\mathrm{H}_{2}\right)$ in the ratio $40: 30: 18: 8: 3$. This result is consistent with the description by Kämpfer et al. (2008). Streptomyces hainanensis YIM $47672^{\mathrm{T}}$ has also been reported to contain an unusual quinone system, composed of MK-9 $\left(\mathrm{H}_{4}\right)$, MK-10 $\left(\mathrm{H}_{0}\right)$, MK-9 $\left(\mathrm{H}_{6}\right)$ and MK-9 $\left(\mathrm{H}_{8}\right)$ in the ratio $45: 27: 14: 14$ (Jiang et al., 2007). The surprising quinone system with predominant MK-10 and MK-11 derivatives in strain YIM $65188^{\mathrm{T}}$ is significantly different from those of S. specialis GW41-1564 ${ }^{\mathrm{T}}$ and S. hainanensis YIM $47672^{\mathrm{T}}$, which are also unique among streptomycetes so far. The $\mathrm{G}+\mathrm{C}$ content of the genomic DNA from strain YIM $65188^{\mathrm{T}}$ was $71.0 \mathrm{~mol} \%$.

An almost-complete 16S rRNA gene sequence of strain YIM $65188^{\mathrm{T}}$, comprising $1440 \mathrm{bp}$, was amplified by PCR and sequenced as described previously (Li et al., 2007). The resultant $16 \mathrm{~S}$ rRNA gene sequence was aligned with corresponding sequences of representatives of the genus Streptomyces (retrieved from GenBank) by using CLUSTAL_X (Thompson et al., 1997). A phylogenetic tree was constructed by using the neighbour-joining tree-making algorithm (Saitou \& Nei, 1987) from MEGA version 4.0 (Tamura et al., 2007). The PHYLIP version 3.6 software package was used to construct a maximum-likelihood tree (Felsenstein, 1981). The topologies of the resultant trees were evaluated by using bootstrap analysis (Felsenstein, 1985), based on 1000 resampled datasets.

Phylogenetic analysis based on 16S rRNA gene sequences revealed that strain YIM $65188^{\mathrm{T}}$ belongs to the genus Streptomyces and, with both treeing methods, it formed a distinct clade with $S$. specialis GW41-1564 $4^{\mathrm{T}}$ and $S$. hainanensis YIM $47672^{\mathrm{T}}$ (Fig. 2). Strain YIM $65188^{\mathrm{T}}$ showed 97.5 and $96.3 \%$ gene sequence similarities to $S$. specialis GW41-1564 ${ }^{\mathrm{T}}$ and S. hainanensis YIM $47672^{\mathrm{T}}$, respectively. All other representatives of the genus Streptomyces exhibited lower sequence similarities to strain YIM $65188^{\mathrm{T}}(<95.2 \%)$. Genomic relatedness between strains YIM $65188^{\mathrm{T}}$ and S. specialis GW41-1564 ${ }^{\mathrm{T}}$ was determined according to the DNA-DNA reassociation method described by He et al. (2005). The experiment was performed with three replicates. The low level of DNADNA relatedness (mean $\pm \mathrm{SD}, 42.7 \pm 1.9 \%$ ) supported the hypothesis that these two strains belong to different genomic species.

Besides the genotypic evidence, strain YIM $65188^{\mathrm{T}}$ can also be distinguished from its closest relatives by additional phenotypic characteristics. S. specialis GW $41-1564^{\mathrm{T}}$ produces a black soluble pigment on all media tested except for nutrient agar, whereas S. hainanensis YIM $47672^{\mathrm{T}}$ produces a light-brown to orange-yellow soluble pigment

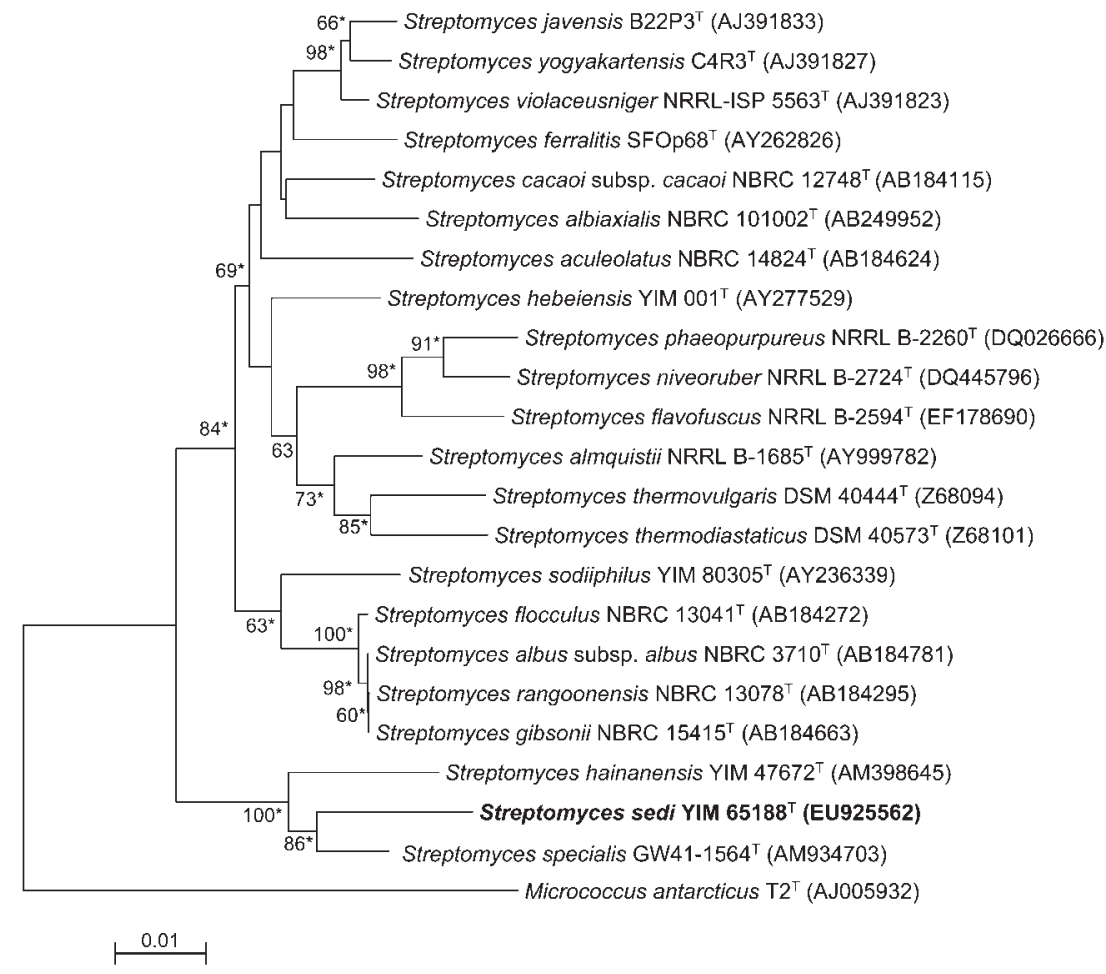

Fig. 2. Neighbour-joining tree based on $16 \mathrm{~S}$ rRNA gene sequences, showing the phylogenetic relationships between strain YIM $65188^{\top}$ and related and representative species of the genus Streptomyces. Bootstrap values (expressed as percentages of 1000 replications) $>50 \%$ are given at nodes. Asterisks indicate clades that were conserved when the maximum-likelihood method was used to construct the phylogenetic tree. Bar, one nucleotide substitution per $100 \mathrm{nt}$. 
on ISP 2, ISP 3, ISP 4 and Czapek's agar (Jiang et al., 2007) and YIM $65188^{\mathrm{T}}$ does not produce soluble pigments on any of the media tested. Furthermore, as shown in Table 1, many differences between strain YIM $65188^{\mathrm{T}}$, S. specialis GW41-1564 ${ }^{\mathrm{T}}$ and S. hainanensis YIM $47672^{\mathrm{T}}$ were detected during determination of carbon- and nitrogen-source utilization. On the basis of the data shown in the present study, we propose that strain YIM $65188^{\mathrm{T}}$ represents a novel species of the genus Streptomyces, for which the name Streptomyces sedi sp. nov. is proposed.

\section{Description of Streptomyces sedi sp. nov.}

Streptomyces sedi (se'di. N.L. gen. n. sedi of Sedum, the plant genus from which this species was isolated).

Forms extensively branched substrate mycelia; aerial mycelia differentiate into spiral spore chains. Spores are elliptical or short rods. Spore surface is smooth. Aerial mycelia are white; vegetative mycelia are yellow-white to light grey-yellow. No soluble pigment is produced. Growth occurs at $15-37{ }^{\circ} \mathrm{C}$ and $\mathrm{pH} 7.0-8.0$. The $\mathrm{NaCl}$ tolerance range is up to $5 \%$. Catalase is produced. Negative for Voges-Proskauer and methyl red tests, oxidase reaction, production of $\mathrm{H}_{2} \mathrm{~S}$, nitrate reduction and milk coagulation and peptonization. Urea and Tweens 20, 40 and 80 are hydrolysed, but cellulose, gelatin and starch are not. Utilizes cellobiose, aesculin, D-fructose and maltose as sole carbon sources. Acid is produced from aesculin and maltose. D-Arabinose, dulcitol, erythritol, D-galactose, inositol, D-lactose, D-mannitol, D-mannose, raffinose, L-rhamnose, D-ribose, sodium malate, D-sorbitol, L-sorbose, trehalose, xylitol and D-xylose are not utilized. L-Alanine, Lcysteine, L-cystine, L-histidine, DL-methionine, L-proline, Lserine and L-tyrosine can be used as sole nitrogen sources, but not adenine, L-arginine, L-asparagine, L-glutamic acid, glycine, hypoxanthine, L-lysine, L-phenylalanine, L-threonine, L-valine or xanthine. The diagnostic amino acid in the peptidoglycan is LL-diaminopimelic acid, and glucose, galactose and madurose are present in whole-cell hydrolysates (cell-wall type I). Phospholipids are diphosphatidylglycerol, phosphatidylethanolamine, phosphatidylglycerol and phosphatidylinositol, with trace amounts of two phosphatidylinositol mannosides and four unknown phospholipids. The quinone system is composed of the major compounds MK-11( $\left.\mathrm{H}_{6}\right)$ and MK-10 $\left(\mathrm{H}_{6}\right)$ and moderate to minor amounts of MK-10 $\left(\mathrm{H}_{8}\right), \mathrm{MK}-11\left(\mathrm{H}_{8}\right)$, MK-9 $\left(\mathrm{H}_{8}\right)$, MK-11 $\left(\mathrm{H}_{4}\right)$, MK-9 $\left(\mathrm{H}_{6}\right)$ and MK-10 $\left(\mathrm{H}_{4}\right)$. The $\mathrm{G}+\mathrm{C}$ content of the genomic DNA of the type strain is $71.0 \mathrm{~mol} \%$.

The type strain, YIM $65188^{\mathrm{T}} \quad(=\mathrm{CCTCC}$ AA $208020^{\mathrm{T}}=\mathrm{DSM} 41942^{\mathrm{T}}$ ), was isolated from a surfacesterilized sample of Sedum sp. collected in Yunnan province, south-west China.

\section{Acknowledgements}

We are grateful to Professor Peter Kämpfer for providing the type strain of S. specialis GW41-1564 ${ }^{\mathrm{T}}$. This research was supported by the National Basic Research Program of China (no. 2004CB719601), the National Natural Science Foundation of China (nos 30560001,
30600001 and 30870005), the Yunnan Provincial International Cooperative Program (no. 2005GH21), the Key Project of Chinese Ministry of Education (no. 206139) and the Ministry of Science and Technology, PR China (2006DFA33550). W.-J. L. was also supported by the Program for New Century Excellent Talent in University (NCET).

\section{References}

Atalan, E., Manfio, G. P., Ward, A. C., Kroppenstedt, R. M. \& Goodfellow, M. (2000). Biosystematic studies on novel streptomycetes from soil. Antonie van Leeuwenhoek 77, 337-353.

Bérdy, J. (2005). Bioactive microbial metabolites, a personal view. J Antibiot (Tokyo) 58, 1-26.

Collins, M. D. \& Jones, D. (1980). Lipids in the classification and identification of coryneform bacteria containing peptidoglycans based on 2,4-diaminobutyric acid. J Appl Bacteriol 48, 459-470.

Collins, M. D., Pirouz, T., Goodfellow, M. \& Minnikin, D. E. (1977). Distribution of menaquinones in actinomycetes and corynebacteria. J Gen Microbiol 100, 221-230.

Coombs, J. T. \& Franco, C. M. M. (2003). Isolation and identification of actinobacteria from surface-sterilized wheat roots. Appl Environ Microbiol 69, 5603-5608.

Dong, X. Z. \& Cai, M. Y. (2001). Manual of Systematics and Identification of General Bacteria. Beijing: Science Press.

Felsenstein, J. (1981). Evolutionary trees from DNA sequences: a maximum likelihood approach. J Mol Evol 17, 368-376.

Felsenstein, J. (1985). Confidence limits on phylogenies: an approach using the bootstrap. Evolution 39, 783-791.

Goodfellow, M. (1971). Numerical taxonomy of some nocardioform bacteria. J Gen Microbiol 69, 33-80.

Gordon, R. E., Barnett, D. A., Handerhan, J. E. \& Pang, C. H.-N. (1974). Nocardia coeliaca, Nocardia autotrophica, and the nocardin strains. Int J Syst Bacteriol 24, 54-63.

He, L., Li, W., Huang, Y., Wang, L. M., Liu, Z. H., Lanoot, B. J., Vancanneyt, M. \& Swings, J. (2005). Streptomyces jietaisiensis sp. nov., isolated from soil in northern China. Int J Syst Evol Microbiol 55, 1939-1944.

Jiang, Y., Tang, S. K., Wiese, J., Xu, L. H., Imhoff, J. F. \& Jiang, C. L. (2007). Streptomyces hainanensis sp. nov., a novel member of the genus Streptomyces. Int J Syst Evol Microbiol 57, 2694-2698.

Kämpfer, P., Huber, B., Buczolits, S., Thummes, K., Wollny, I. G. \& Busse, H. J. (2008). Streptomyces specialis sp. nov. Int J Syst Evol Microbiol 58, 2602-2606.

Kelly, K. L. (1964). Inter-Society Color Council - National Bureau of Standards Color-Name Charts Illustrated with Centroid Colors. Washington, DC: US Government Printing Office.

Kim, S. B. \& Goodfellow, M. (2002). Streptomyces thermospinisporus sp. nov., a moderately thermophilic caboxydotrophic streptomycete isolated from soil. Int J Syst Evol Microbiol 52, 1225-1228.

Kim, S. B., Lonsdale, J., Seong, C. N. \& Goodfellow, M. (2003). Streptacidiphilus gen. nov., acidophilic actinomycetes with wall chemotype I and emendation of the family Streptomycetaceae (Waksman and Henrici $(1943)^{\mathrm{AL}}$ ) emend. Rainey et al. 1997. Antonie van Leeuwenhoek 83, 107-116.

Li, W., Lanoot, B., Zhang, Y., Vancanneyt, M., Swings, J. \& Liu, Z. (2002). Streptomyces scopiformis sp. nov., a novel streptomycete with fastigiated spore chains. Int J Syst Evol Microbiol 52, 1629-1633.

Li, W. J., Xu, P., Schumann, P., Zhang, Y. Q., Pukall, R., Xu, L. H., Stackebrandt, E. \& Jiang, C. L. (2007). Georgenia ruanii sp. nov., a 
novel actinobacterium isolated from forest soil in Yunnan (China) and emended description of the genus Georgenia. Int J Syst Evol Microbiol 57, 1424-1428.

Locci, R. (1989). Streptomyces and related genera. In Bergey's Manual of Systematic Bacteriology, vol. 4, pp. 2451-2508. Edited by S. T. Williams, M. E. Sharpe \& J. G. Holt. Baltimore: Williams \& Wilkins.

Manfio, G. P., Zakrzewska-Czerwinska, J., Atalan, E. \& Goodfellow, M. (1995). Towards minimal standards for the description of Streptomyces species. Biotechnologia 8, 228-237.

Manfio, G. P., Atalan, E., Zakrzewska-Czerwinska, J., Mordarski, M., Rodriguez, C., Collins, M. D. \& Goodfellow, M. (2003). Classification of novel soil streptomycetes as Streptomyces aureus sp. nov., Streptomyces laceyi sp. nov. and Streptomyces sanglieri sp. nov. Antonie Van Leeuwenhoek 83, 245-255.

Mesbah, M., Premachandran, U. \& Whitman, W. B. (1989). Precise measurement of the $\mathrm{G}+\mathrm{C}$ content of deoxyribonucleic acid by highperformance liquid chromatography. Int J Syst Bacteriol 39, 159-167.

Minnikin, D. E., Collins, M. D. \& Goodfellow, M. (1979). Fatty acid and polar lipid composition in the classification of Cellulomonas, Oerskovia and related taxa. J Appl Bacteriol 47, 87-95.

Saitou, N. \& Nei, M. (1987). The neighbor-joining method: a new method for reconstructing phylogenetic tree. Mol Biol Evol 4, 406425 .

Sembiring, L., Ward, A. C. \& Goodfellow, M. (2000). Selective isolation and characterization of members of the Streptomyces violaceusniger clade associated with roots of Paraserianthes falcataria. Antonie Van Leeuwenhoek 78, 353-366.

Shirling, E. B. \& Gottlieb, D. (1966). Methods for characterization of Streptomyces species. Int J Syst Bacteriol 16, 313-340.

Staneck, J. L. \& Roberts, G. D. (1974). Simplified approach to identification of aerobic actinomycetes by thin layer chromatography. Appl Microbiol 28, 226-231.

Tamaoka, J., Katayama-Fujimura, Y. \& Kuraishi, H. (1983). Analysis of bacterial menaquinone mixtures by high performance liquid chromatography. J Appl Bacteriol 54, 31-36.

Tamura, K., Dudley, J., Nei, M. \& Kumar, S. (2007). MEGA4: molecular evolutionary genetics analysis (MEGA) software version 4.0. Mol Biol Evol 24, 1596-1599.

Thompson, J. D., Gibson, T. J., Plewniak, F., Jeanmougin, F. \& Higgins, D. G. (1997). The CLUSTAL_X windows interface: flexible strategies for multiple sequence alignment aided by quality analysis tools. Nucleic Acids Res 25, 4876-4882.

Waksman, S. A. \& Henrici, A. T. (1943). The nomenclature and classification of the actinomycetes. J Bacteriol 46, 337-341.

Williams, S. T., Goodfellow, M., Alderson, G., Wellington, E. M. H., Sneath, P. H. A. \& Sackin, M. J. (1983). Numerical classification of Streptomyces and related genera. J Gen Microbiol 129, 1743-1813.

Xu, P., Li, W. J., Tang, S. K., Zhang, Y. Q., Chen, G. Z., Chen, H. H., Xu, L. H. \& Jiang, C. L. (2005). Naxibacter alkalitolerans gen. nov., sp. nov., a novel member of the family Oxalobacteraceae isolated from China. Int J Syst Evol Microbiol 55, 1149-1153. 